\title{
English parenting for Japanese parents
}

\author{
JANICE NAKAMURA
}

Kanagawa University, Japan

\author{
A critical review of advice in self-help books for raising \\ bilingual children in Japan
}

\section{Introduction}

The popularity of English in early foreign language teaching is a global phenomenon. Parents and policymakers in Europe are eager to expose young children to a foreign language, which is usually English (De Houwer, 2015). Likewise, in Japan, English is the de facto foreign language subject in schools (Sakamoto, 2012). The introduction of English education in lower elementary grades and the use of English examination scores to enter schools or universities or gain employment has made English more important than ever. These educational policies motivate many Japanese parents to send their children for English lessons or enroll them in English preschools or after-school programs. Attending an international school is a definite way to acquire high English proficiency, but not every family can afford the high tuition.

An alternative to expensive English education is English immersion at home. Self-help bilingual parenting books in Japan advocate eigo de kosodate or English parenting. The term is used synonymously with bilingual parenting because of English's prestige in Japan. Japan is not the only Asian country with an interest in English parenting. Parents in Korea who are obsessed with their children's English language learning speak English to them (Seo, 2021). Many parents base their bilingual parenting decisions on self-help literature (King \& Fogle, 2006), so such books may popularize English parenting. This paper critically evaluates English parenting literature in Japan by asking the following questions:

i. What are the main arguments put forth by Japanese bilingual parenting books in recommending English parenting? ii. What are their common suggestions for English parenting, and to what extent are they based on research evidence?

\section{Parenting in a foreign language}

The perceived benefits of bilingualism can motivate some parents to speak a foreign language to their children. Books written for English-speaking parents have encouraged foreign language use with children. Jernigan (2015: 34) suggests that 'any language skills are a good place to start,' and Gibson (2011) proposes that parents can teach their children another language no matter how little they know. However, three case studies suggest that proficiency in the foreign language is essential.

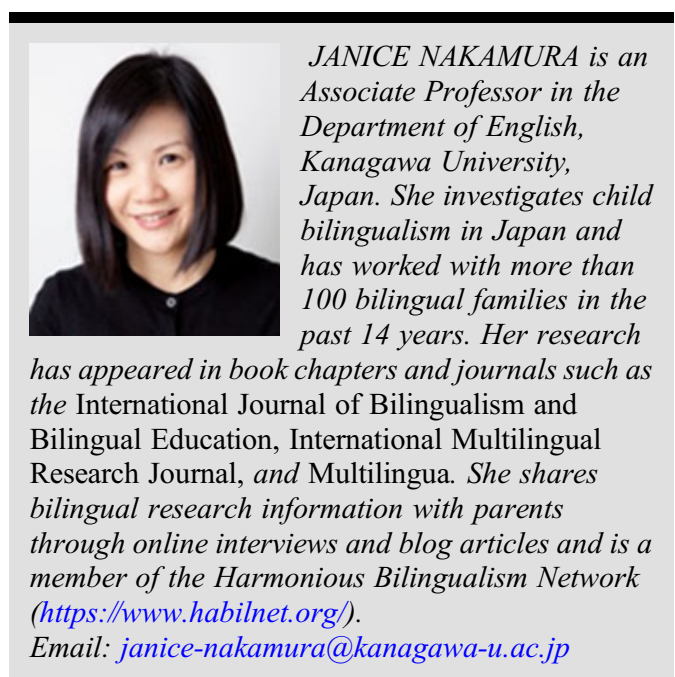


Saunders (1982) was an Australian father with a doctoral degree in German linguistics. His high fluency enabled him to communicate confidently in German with his children. Although he was their only source of German input in Australia, they became fluent German speakers who could converse comfortably with native speakers. Likewise, the Thai mother in Nakamura (2015) could speak Japanese to her child because she had lived in Japan for more than 12 years. By contrast, Kouritzin (2000) did not know how a Japanese mother would speak to her child. She struggled to read stories in Japanese and model the language correctly to her children in Canada. Fortunately for Kouritzin, her children also received Japanese exposure from their Japanese father.

Larger US studies indicate that it is the input from native speakers and not from parents with limited proficiency that determines children's English vocabulary and grammatical development (Hoff et al., 2014; Place \& Hoff, 2011). The speech of parents with limited English proficiency differs from that of native speakers on various linguistic measures positively associated with children's language growth (Hoff, Core \& Shanks, 2020). It also differs from that of parents with good English proficiency. These studies show that parents' language proficiency can affect the child's language development. The quality of parental input is particularly crucial when there is no additional exposure to the speech of fluent or native speakers.

\section{Books on bilingual parenting in Japan}

A growing interest in bilingual parenting in Japan is evident in the many self-help books published on the subject in recent years. Japanese titles on bilingual parenting probably outnumber those available in English and other languages (De Houwer \& Nakamura, accepted for publication 2021). This paper reviews 17 of these publications (cf. Table 1). Written by educators and parents who have raised bilingual children, these books have attractive titles such as 'A magical method for raising any child as a bilingual' (Funatsu, 2011; Table 1; author's translation from Japanese).

These books were coded and analyzed according to the constructive grounded theory approach (Charmaz, 2014) using MAXQDA, a qualitative data analysis software. Firstly, initial codes were assigned to the themes which emerged from line-by-line reading of the text. Then, they were subsumed into focused codes, which were subsequently grouped into clusters of the same theme. Memos were written for the largest clusters of codes to help raise them to conceptual categories. Finally, theoretical sampling was performed by retracing the categories to the data and using the data to explicate them. More than 2,000 codes were generated from the text analysis. This paper will discuss the results from the two most frequently recurring themes: 1) arguments for English parenting (431 codes), and 2) suggestions for English parenting (1,331 codes).

\section{Arguments for English parenting}

'The earlier, the better' (176 codes) and 'the advantages of knowing English and being bilingual' (149 codes) were the most common arguments for English parenting. Some books encourage giving early English exposure so that children acquire native-like English pronunciation. Sampei (2016, Table 1) suggests that English should be acquired early because it would be difficult to do so in adulthood. She claims that children will naturally speak English once they understand it, contradicting evidence that many bilingual children do not speak one of their two languages (De Houwer, 2020). Only a few books assure parents that it is never too late to start.

The age factor is not fully discussed in many of these books. Authors advocate early English learning without acknowledging that young immigrant children's relative success in language learning relates to their immersive English environment (Johnson \& Newport, 1989). However, in a foreign language learning setting, older children are more efficient learners (e.g., Muñoz \& Singleton, 2011; Pfenninger \& Singleton, 2016). In Germany, children who started learning English in Grade 3 did better in English tests in Grade 7 than those who started in Grade 1 (Jaekel et al., 2017). Moreover, 14 of the 17 books did not provide a reference list. Much of their advice is based on the authors' experiences as parents and educators. Only Kohri (2002, Table 1) surveyed Japanese parents' efforts to teach English at home. However, without reference to research, the authors are only perpetuating the popular myth that the earlier, the better it is for foreign language learning.

'The advantages of knowing English or being bilingual' is another common argument. Most books mention how educational reforms in Japan are making English increasingly important. Therefore, English parenting is advocated as a way to give children a brighter future. Some books encourage an academic-oriented approach that focuses on passing English examinations (e.g., Hirotsuru, 2017; Masaki, 2012; Matsui, 2018; Saito, 2017; Table 1). They give examples of 


\section{Table 1: List of bilingual parenting books in Japan}

1. Drennan, Henry [ヘンリードレナン]. 2018. ヘンリーおじさんの英語で子育てができる本 [Uncle Henry's English Parenting Can-Do Book]. Tokyo: Alc.

2. Funatsu, Hiroshi [船津洋]. 2011.どんな子でもバイリンガルに育つ魔法のメリッド [A Magical Method for Raising any Child as a Bilingual]. Tokyo: Sogo Horei.

3. Hirakawa, Yuki [平川裕貴]. 2015. お金をかけずにわが子をバイリンガルにする方法 [How to Raise Your Child as a Bilingual without Spending Money]. Tokyo: Saizusha.

4. Hirotsuru, Mari [廣津留真理]. 2017. 英語で一流を育てる [Bringing up Elites in English]. Tokyo: Diamond.

5. Ihara, Kaori [井原香織]. 2004. 井原さんちの英語で子育て [English Parenting at the Iharas' Home]. Tokyo: Gakken.

6. Kinoshita, Kazuyoshi [木下和好]. 2001. 子どもをバイリンガルに育てる方法 [The Way to Raise Children as Bilinguals]. Tokyo: Diamond.

7. Kohri, Nora [コーリ .ノーラ]. 2002. 英語のできる子どもに育てる [Raising a Child who Masters English]. Tokyo: Japan Times.

8. Masaki, Fumiko [柾木史子]. 2012. わが子を知的バイリンガルに育てる方法 [The Way to Bring up Your Child as an Intellectual Bilingual]. Tokyo: Godo Forest.

9. Matsui, Yoshiaki [松井義明] .2018. 楽しい「子ども英語」はなぜ身につかないの? [Why Does 'English for Kids' Fail?]. Tokyo: Poplar.

10. Oda, Setsuko [小田せつこ]. 2019. 子どもの未来を広げる「おやこえいご」:バイリンガルを育てる幼 児英語メソッド ['Parent-Child English' to Broaden Your Child's Future: English Methods for Bilingual Child-Raising]. Tokyo: Petite Lettre.

11. Parker, Robert A. [ロバート．A. パーカー]. 2014.バイリンガルは「茶の間」で育つ! [Raise Bilinguals from Your Living Room!]. Tokyo: President.

12. Saito, Jun. [斉藤淳]. 2017. ほんとうに頭がよくなる世界最高の子ども英語 [Cultivating Intelligence through Language Acquisition: Practical English for Developing Children]. Tokyo: Diamond.

13. Sakae, Yoko [栄 陽子]. 2019. 子どもを‘゙イリンガル’にしたければこう育てなさい![If You Want Your Children to be Bilinguals, Raise Them like This!]. Tokyo: Fusosha.

14. Sampei, Mari [三幣真理]. 2016. バイリンガルは5 歳までにつくられる [Creating Bilinguals up to the Age of 5]. Tokyo: Gentosha.

15. Shichida, Makoto [七田眞 ]. 2001. 英語のできる子の育て方 [The Way to Bring up a Child who Masters English]. Tokyo: PHP.

16. Shufunotomo. [主婦の友社]. 2020. おうちでほぼバイリンガルの育て方 [An Almost Bilingual Upbringing in the Home]. Tokyo: Shufunotomo.

17. Takahashi, Nagako [高橋 良子]. 2019. びりちゃんのバイリンガル日記: 日本語と英語を自由に使える 子どもの育て方 [Bili-chan's Bilingual Diary: The Way to Raise a Child Who Can Use English and Japanese Freely]. Tokyo: Bungeisha.

children with high English proficiency who successfully entered prestigious schools and universities in Japan and abroad to illustrate how English parenting can lead to academic success.

\section{Suggestions for English parenting}

Many of the suggestions help counter the lack of authentic English input and interaction in Japan, i.e., giving English exposure through media (284 codes) and speaking English to the child (174 codes). Many books recommend media as the primary source of English input because Japanese parents may not be proficient in English. Oda (2019, Table 1) asserts that videos give the best input because the length of exposure for videoviewing is longer than for book-reading. Her claim contradicts findings that book-reading benefits the development of a non-societal language more than TV-watching (Bosma \& Blom, 2020). Moreover, Oda recommends two hours of daily video-viewing from the very young age of 18 months and withholding Japanese TV programs to maintain children's interest in English. Likewise, Funatsu (2011, Table 1) assures parents that their use of English is unnecessary. They can recreate an English environment at home by continuously playing CDs or DVDs. Takahashi (2019, Table 1) is the only critic of this method. 
She did not want animated chatter from English media to disrupt her time with her child. These books hardly caution parents about overexposing young children to media or leaving them to watch videos on their own. Except for Kinoshita (2001, Table 1) and Kohri (2002, Table 1), none of them advise parents to watch the videos with their children and to talk about them.

Most of these books also insist that high English proficiency is not required. Parents only need to use some English to supplement other input sources, i.e., lessons, media, and books. Specifically, parents can use simple English expressions in some daily routines. Some books even include a list of useful English phrases for them to try. Two parent-authored books give accounts of full English use. Ihara (2004, Table 1) explains how speaking English felt unnatural at first, but she gradually became accustomed to it. Takahashi (2019, Table 1) initially disapproved of using English because she was not a native speaker. However, she switched to English later to accelerate her child's English learning.

\section{Discussion}

Non-native parents' use of English to children is not novel. Many immigrant parents in countries where English is the dominant societal language (e.g., the US) speak English to their children, and so do fluent English-speaking parents in countries where English is a second language (e.g., Malaysia). However, the availability of self-help bilingual parenting books in Japan indicates interest in English parenting among parents who speak it as a foreign language. Research shows that proficiency is crucial when parenting in a nonnative language. Children would not acquire a language when they only hear bits of it from a parent with low proficiency. When the language only makes up $20 \%$ of a child's input, it would not support active language use (Pearson \& Amaral, 2014). Children receiving low levels of input are very reluctant to use that language and tend to tune it out (Pearson et al., 1997). An exposure of $40 \%$ to $60 \%$ is needed to achieve receptive vocabulary within the range of monolingual children and approximately $70 \%$ for expressive vocabulary (Thordardottir, 2014).

Many books suggest that parents can make up for their low English proficiency by exposing their children to English media. Etsuko Kida in Shufutomo (2020, Table 1) and Oda (2019, Table 1) prescribe two hours of video-viewing a day, or 14 hours a week. Combined with a one- hour weekly English class (as recommended by Oda, 2019, Table 1), weekly English exposure only amounts to 15 hours, or $17.9 \%$ of a child's waking hours (based on a 12-hour day for seven days). This exposure is not enough to support English production. Even when parents' occasional English input increases exposure to $20 \%$, it is still too low. Arguably, English exposure need not be high because Japanese parents may be satisfied with their children having only some receptive ability. However, if parents do not speak English, it is hard for them to assess their children's receptive ability. They will likely look at English production as a measure of progress and might be disappointed when they find that their children cannot speak English after following English parenting advice.

Moreover, TV viewing is usually not used to quantify children's language exposure (Thordardottir, 2014). Input must be direct, i.e., the child needs to interact with speakers of the language (Pearson et al., 1997). The documented inability of a hearing child of deaf parents to acquire spoken language from television (Sachs, Bard \& Johnson, 1981) demonstrates the inadequacy of such impersonal language sources. Television viewing only benefits language development when parents and children talk about what they watched together (Lemish \& Rice, 1986). English TV viewing by Singaporean kindergarteners from non-English-speaking homes improved their English vocabulary, but they were also exposed to English in kindergarten (Dixon, 2011). English television viewing also facilitated Dutch schoolchildren's English vocabulary growth because they could already read the Dutch subtitles to decipher the English meanings independently (Koolstra \& Beentjes, 1999). It is a different matter when media is an almost exclusive source of English for young children.

English parenting books also assure parents that they can speak English to their children regardless of their proficiency. For this purpose, English parenting phrasebooks are also available in Japan. Hirakawa (2015, Table 1) insists that the English used with young children is simple, so it is not difficult for parents to speak it. However, research shows that input from parents with limited English proficiency does not benefit language development (Hoff et al., 2020). Without some degree of fluency, it would be difficult to sustain interactions with children and provide rich input for their language growth. Our foreign language proficiency determines how well we perform tasks such as ordering a meal or giving directions. 
The issue of language proficiency is no different when it comes to parenting a child.

Nevertheless, some of these books claim that their method is tried and tested. The authors' success in raising their own children as bilinguals is probably attributed to other factors, namely their high English proficiency. Many parent-authors have studied in English-speaking countries or worked as English teachers, interpreters, and translators (e.g., Kinoshita, 2001; Oda, 2019; Takahashi, 2019; Table 1). Their children were also precocious learners. Hirotsuru's (2017, Table 1) daughter could already read in English and Japanese at age two. Others passed difficult English examinations at young ages. The model children in these books help build the case for English parenting, but they do not represent the typical Japanese child. Moreover, authors who operate English preschools and cram schools put children through rigorous academic-focused English programs (e.g., Masaki 2012; Saito 2017; Table 1), which are difficult for parents to replicate at home. Therefore, these books do not adequately discuss the necessary conditions for successful English parenting.

There are implications for Japanese parents with low English proficiency who follow the advice of these books. Particularly in the first three years of life, the time used for speaking English is probably better spent interacting in Japanese with the child. Parents' native language is richer and benefits children's language development more than a foreign language. Also, English video-watching would reduce the time for explorative play and actual interaction, which are critical for children's overall development. Media is not a replacement for human interaction, so parents need to assess whether they are proficient enough in English support their children's English learning in the long term.

\section{Conclusion}

'The earlier, the better' is the common argument Japanese self-help books put forth to encourage English parenting. However, their argument and the suggestion for parents to immerse young children in English media are not based on research evidence, so English parenting may have implications for children's development. While this paper focused on English parenting in Japan, there is similar interest in other countries where English is spoken as a foreign language (e.g., Korea). Foreign language parenting books in English also indicate interest in the subject in Western societies. Therefore, foreign language parenting may become a more common global phenomenon in the future. Parenting in any foreign language is no easy task, so parents need to be aware of research-based information, particularly concerning proficiency levels and media use. Child language researchers can play a bigger role in disseminating research knowledge to help parents make the correct decisions.

\section{Funding}

This work was supported by the Japan Society for the Promotion of Science under the Grant-in-Aid for Scientific Research (C) (21K00797).

\section{References}

Bosma, E. \& Blom, E. 2020. 'Language activities in a minority-majority language context: Book-reading at home is more important for Frisian than for Dutch.' Journal of Child Language, 47, 289-308.

Charmaz, K. 2014. Constructing Grounded Theory (2nd edn.) London: Sage.

De Houwer, A. 2015. 'Early foreign language teaching: Some critical remarks and some recommendations.' Babylonia, 1(14). 14-21.

De Houwer, A. 2020. 'Why do so many children who hear two languages speak just a single language?' Zeitschrift für Interkulturellen Fremdsprachenunterricht, 25(1), 7-26.

De Houwer, A. \& Nakamura, J. Accepted for publication 2021. 'Developmental perspectives on parents' use of discourse strategies with bilingual children.' Routledge.

Dixon, Q. L. 2011. 'The role of home and school factors in predicting English vocabulary among bilingual kindergarten children in Singapore.' Applied Psycholinguistics, 32(1), 141-168.

Gibson, C. 2011. Catching Tongues: How to Teach Your Child a Foreign Language even if You Don't Speak One Yourself. US: Carolyn Gibson.

Hoff, E., Core, C. \& Shanks, K. 2020. 'The quality of child-directed speech depends on the speaker's language proficiency.' Journal of Child Language, 47(1), 132-145.

Hoff, E., Welsh, S., Place, S. \& Ribot, K. M. 2014. 'Properties of dual language input that shape bilingual development and properties of environment that shape dual language input.' In T. Grüter \& J. Paradis (eds.), Input and Experience in Bilingual Development. Amsterdam: John Benjamins, pp. 119-140.

Jaekel, N., Schurig, M., Florian, M. \& Ritter, M. 2017. 'From early starters to late finishers? A longitudinal study of early foreign language learning in school.' Language Learning, 67(3), 631-664.

Jernigan, C. 2015. Family Language Learning. Bristol: Multilingual Matters.

Johnson, J. \& Newport, E. 1989. 'Critical period effects in second language learning: The influence of maturational state on the acquisition of English as a second language.' Cognitive Psychology, 21(1), 60-99.

King, K. \& Fogle, L. 2006. 'Bilingual parenting as good parenting: Parents' perspectives on family language policy 
for additive bilingualism.' International Journal of Bilingual Education and Bilingualism, 9(6), 695-712.

Koolstra, C. M. \& Beentjes, J.W. J. 1999. 'Children's vocabulary acquisition in a foreign language through watching subtitled television programs at home.' Educational Technology Research and Development, 47(1), 51-60.

Kouritzin, S. G. 2000. 'A mother's tongue.' TESOL Quarterly, 34(2), 311-324.

Lemish, D. \& Rice, M. L. 1986. 'Television as a talking picture book: A prop for language acquisition.' Journal of Child Language, 13(2), 251-274.

Muñoz, C. \& Singleton, D. 2011. 'A critical review of age-related research on L2 ultimate attainment.' Language Teaching, 44(1), 1-35.

Nakamura, J. 2015. 'Non-native maternal input: Language use and errors in a Thai mother's interactions in Japanese with her child.' Japan Journal of Multilingualism and Multiculturalism, 21(1), 10-26.

Pearson, B. \& Amaral, L. 2014. 'Interactions between input factors in bilingual language acquisition: Considerations for minority language maintenance.' In T. Grüter \& J. Paradis (eds.), Input and Experience in Bilingual Development. John Benjamins: Amsterdam, pp. 99-117.

Pearson, B., Fernandez, S., Lewedeg, V. \& Oller, K. D. 1997. 'The relation of input factors to lexical learning by bilingual infants.' Applied Psycholinguistics, 18(1), 41-58.

Pfenninger, S. \& Singleton, D. 2016. 'Affect trumps age: A person-in-context relational view of age and motivation in SLA.' Second Language Acquisition, 32(3), 311-345.

Place, S. \& Hoff, E. 2011. 'Properties of dual language exposure that influence 2-year-olds' bilingual proficiency.' Child Development, 82(6), 1834-1849.

Sachs, J., Bard, B. \& Johnson, M. 1981. 'Language learning with restricted input: Case studies of two hearing children of deaf parents.' Applied Psycholinguistics, 2(1), 33-54.

Sakamoto, M. 2012. 'Moving towards effective English language teaching in Japan: Issues and challenges.' Journal of Multilingual and Multicultural Development, 33(4), 409-420.

Saunders, G. 1982. Bilingual Children: Guidance for the Family. Multilingual Matters: Clevedon.

Seo, Y. 2021. 'Parental language ideologies and affecting factors in bilingual parenting in Korea.' English Teaching, 76(1), 105-124.

Thordardottir, E. 2014. 'The typical development of simultaneous bilinguals: Vocabulary, morphosyntax and language processing in two age groups of Montreal preschoolers.' In T. Grüter \& J. Paradis (eds.), Input and Experience in Bilingual Development. John Benjamins: Amsterdam, pp.141-160. 